\title{
Development of Sumitomo High Toughness (SHT) Process for \\ Low Temperature Service Steels*
}

\section{By Toshio IKESHIMA**}

\section{Introduction}

So far, Sumitomo Metal Industries, Ltd. has investigated and examined the method of producing economically a large amount of steel plates having excellent low temperature toughness which are applicable for low temperature service steels such as gas transportation steel pipelines in the extreme north. As a result of the investigation, we have successfully developed a new thermo-mechanical treatment method and production process ensuring the economy and productivity peculiar to controlled rolling process and the uniformity of steel properties peculiar to heat treatment process. The developed thermo-mechanical method and production process were named SHT process and adopted in the plate mill of Kashima Steel Works, for which the specialized facilities were installed. Production by this process was started in August, 1975. Being capable of saving energy and resources, the SHT process ensures the cutting-down of production cost for the producer as well as welding cost for the users owing to excellent weldability.

In 1979, the Okochi Memorial Grand Production Prize (one of Japan's most prestigious industrial awards for individuals and enterprises making significant contributions to the promotion of production engineering) was awarded to us for the works of "Development of Production Method of Low Temperature Service Steels with High Toughness." A brief explanation thereof is given below.

\section{Background of Development}

In 1969 three Japanese mills received the order of delivery of large diameter steel pipes (500 000 tons) for TAPS (Trans Alaska Pipeline System) designated to transport oil from the northern part of Alaska to America. The required low temperature toughness was $50 \mathrm{ft}-\mathrm{lb}(6.9 \mathrm{~kg}-\mathrm{m})$ in the longitudinal direction of the pipe and $25 \mathrm{ft}-\mathrm{lb}(3.5 \mathrm{~kg}-\mathrm{m})$ in the circumferential direction of the pipe at $-10^{\circ} \mathrm{C}$ (in case of Charpy impact test). This toughness could be obtained only by the steel making process and controlled rolling process of the highest technical level at the time. ${ }^{1)}$

Taking the possible increase in pipeline projects in the cold districts into consideration, in 1967 we embarked on extensive fundamental researches on lowtemperature toughness required for gas transportation steel pipes in the cold districts as well as on the methods of producing these pipes, the Central Research Laboratories played a leading role. The production of line pipes for TAPS was the first attempt to apply the achievements of our researches.

Since gas transportation steel pipes in the northernmost region must be laid in a limited period due to severe climatic conditions, a colossal number of steel pipes have to be supplied in a short term. Hence, much attention must be given not only to low temperature toughness but also to productivity and economy. The recent demands have promoted remarkable progress in the production process of high tensile steel plates for low temperature service by the controlled rolling method.

However, with progress in the exploitation of energy resources the conditions of pipeline projects have become stricter and less favorable. For example, excessively low ambient temperatures in the Arctic Circle or Siberia, etc. necessitate further improved low temperature toughness, and at present, moreover, so as to improve the transportation efficiency, an increase in the strength and wall thickness of the steel pipes is required. ${ }^{2}$ As the conventional controlled rolling process is almost incapable of producing the line pipes for cold regions which can satisfy these requirements, a new method of producing low temperature service steels is required. The SHT process has been developed to answer this need. As mentioned below, it has the advantages peculiar to the controlled rolling process and the heat treatment process.

\section{Outline of SHT Process}

\section{Brief Explanation of SHT Process}

The SHT process has been developed as a result of efforts made to establish a production method which enables us to supply economically a large amount of steel plates having excellent low temperature toughness in the shortest possible period for use in the coldest districts. So to accomplish the aim we have examined basically a new thermo-mechanical treatment method based on the principle given in Section III.2. and developed the facilities and production process for this method. The development of the SHT process has been performed based on the following three factors:

1) Development of thermo-mechanical treatment method,

2) Development of mass-production process,

3) Development of computer control.

As to this process 23 patents have been applied.

* Originally published in Tetsu-to-Hagané, 65 (1979), 1644, in Japanese. English version received December 19, 1979.

** Vice-President, Sumitomo Metal Industries, Ltd., Kitahama, Higashi-ku, Osaka 541. 


\section{Principle of SHT Process}

In the toughness increasing mechanism of steel, the SHT process combines the following four effects depending on the required properties of the steel plate:

1) Effect of grain refining. ${ }^{3,4)}$

2) Effect of precipitation hardening. ${ }^{5,6)}$

3) Effect of work hardening. ${ }^{7,8)}$

4) Effect of transformation hardening. ${ }^{91}$

Of all these effects the effect (1) is maximally utilized as the basic effect for SHT steel plate (hereinafter the steel plate produced by the SHT process is called SHT steel plate). The other three effects have been regarded to be favorable for intensification, however they may adversely affect the toughness of asrolled or normalized steel. In the SHT process the abovementioned effects are applied successfully by heating to a temperature just above the transformation point $\mathrm{A}_{\mathrm{c} 3}$ of steel and then rolling without an adverse influence on toughness. ${ }^{5-9}$ )

For grain refining the SHT process takes the following 4-step mechanisms:

A) Refining of initial austenite grain by heating steel to just above the point $\mathrm{A}_{\mathrm{c} 3},{ }^{3)}$

B) Grain refining by recrystallization zone rolling of austenite,

C) Introduction of deformation band by non-recrystallization zone rolling of austenite (apparent growth of grain boundary), ${ }^{4}$

D) Grain refining by dynamic recovery or recrystallization of deformed ferrite by austenite-ferrite intercritical zone rolling. ${ }^{3,8)}$

We have worked out the 2-heating and 2-rolling process shown in Fig. 1 which enables us to realize the grain refining mechanism A) D) in mass-production line without lowering economy. As shown in Fig. 2 the conventional heat treatment method utilizes only the mechanism A). The thermo-mechanical treatment method worked out by R. H. Grange ${ }^{10}$ utilized the mechanisms A) and B) for grain refining. The controlled rolling method utilizes the mechanisms B) $\sim$ D), but it is 1-heating and 1-rolling process. Therefore, it imposes various limits on the correlation between the optimum rolling conditions for toughness and the productivity, etc., which results in the restricted performance of the mechanisms, hence causing limited toughness level. The SHT process enables us to utilize the mechanisms A) D) depending on the required toughness, allowing us to obtain the properties not lower than those obtained by the conventional methods.

Figure 3 shows the change of microstructure in the SHT process in comparison with that observed in the controlled rolling process and normalizing process. ${ }^{11}$ In the controlled rolling process, steel of 5 to $10 \mu$

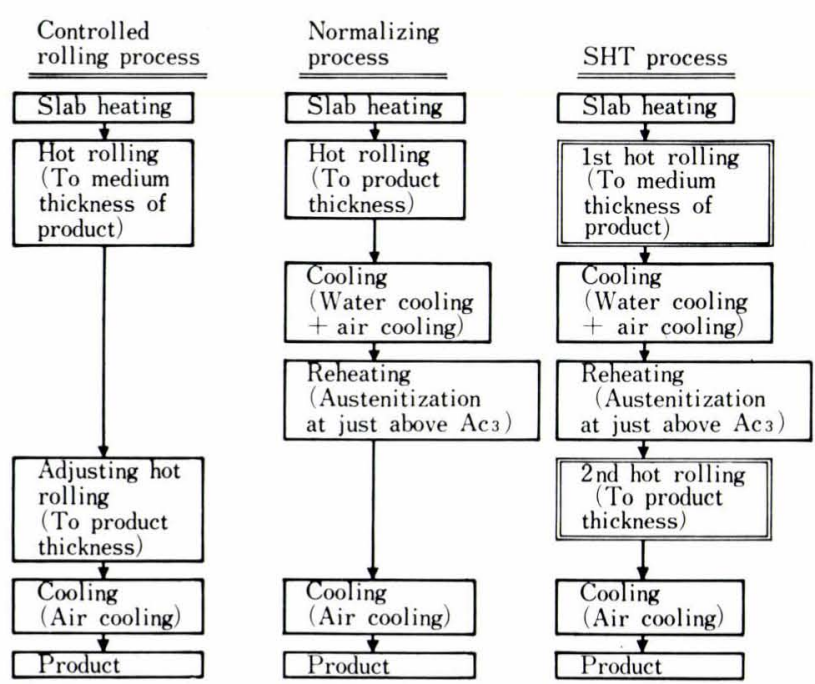

Fig. 1. Comparison of SHT, ordinary controlled rolling and normalizing processes.

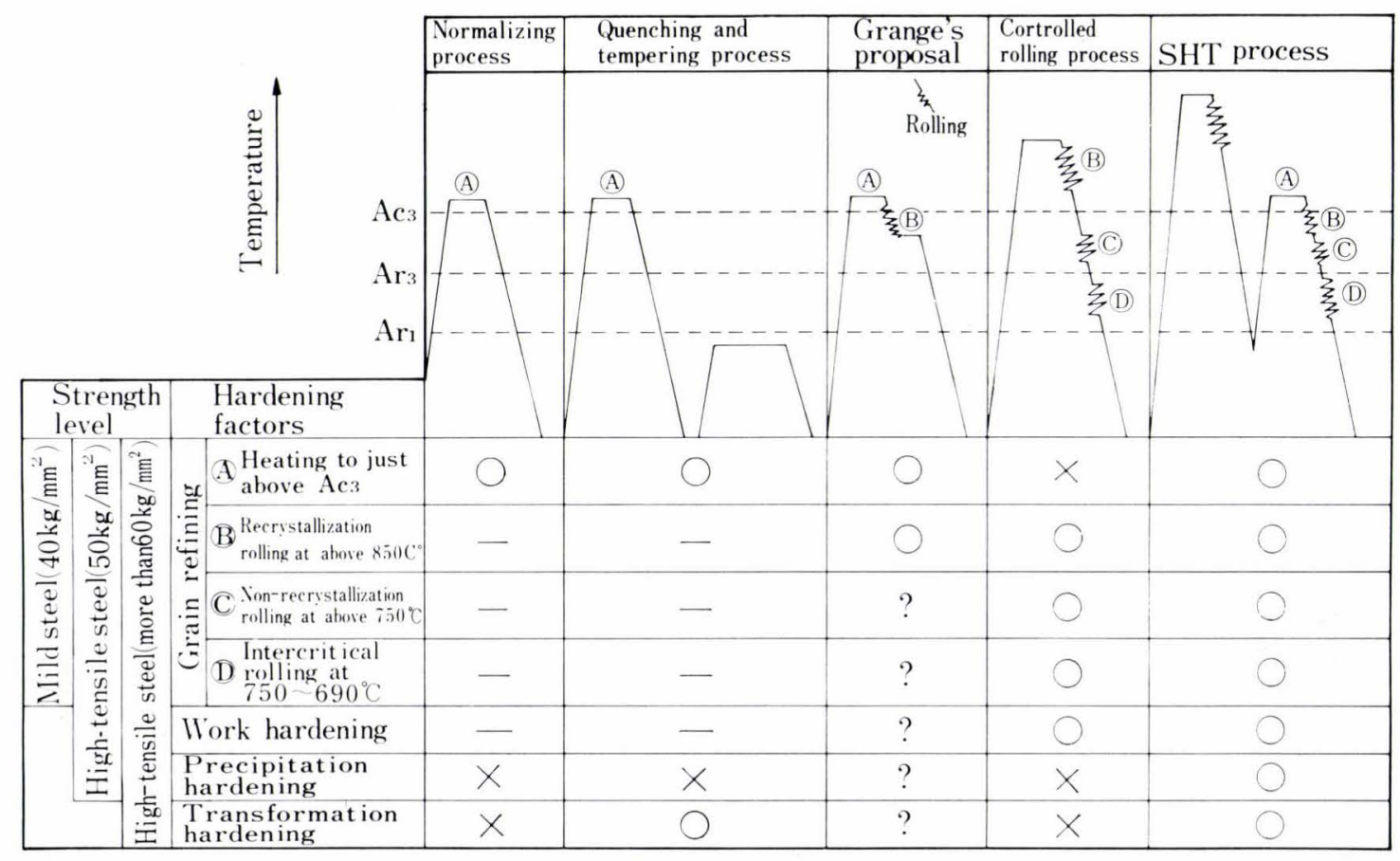

Fig. 2. Influences of hardening factors of low temperature service steel on toughness. 
grain can be easily obtained. However, as compared with the microstructure of the steel produced by the SHT process, the grains of steel obtained by the controlled rolling are coarse and nonuniform due to the growth of austenite grains resulting from high slab heating temperature $\left(1100^{\circ}\right.$ to $\left.1250^{\circ} \mathrm{C}\right)$. In the normalizing process, on the other hand, the austenite grains are turned to well arranged fine grains by reheating to just above the transformation point $\mathrm{A}_{\mathrm{c} 3}$ after rolling, finally allowing us to obtain a uniform microstructure. However, since, the ferrite grain size depends on the austenite grain size, it is difficult to promote grain refining above the standard level. The SHT process combines the advantages of both processes. The final heating temperature is made approximately equal to that of the normalizing process, i.e., $900^{\circ}$ to $950^{\circ} \mathrm{C}$, which enables us to obtain well arranged fine austenite grains. Then, the thermomechanical processing is performed to obtain a finer microstructure. Photograph 1 shows the microstructures of steel plates of the same thickness and the same chemical composition produced by the SHT process, the controlled rolling process and the normalizing process, respectively.

\section{Development of Production Process}

To make use of the specific toughness increasing mechanisms, in the SHT process, 2-heating and 2rolling are performed. As a result of examination of the possibility of performing " 2-heating and 2-rolling " in the existing rolling mill (plate mill in Kashima Steel Works) without lowering the performance of the mill, a production process was developed as follows:

1) Examination of layout,

2) Development of reheating furnace control system, 3) Introduction of combined rolling system and development of rolling control system.

Figure 4 shows the shop layout and the computer control system worked out based on the abovementioned conception. For the rolling line provided with the 1st and 2nd rolling mills, a SHT line equipped with cooling unit and reheating furnace was installed

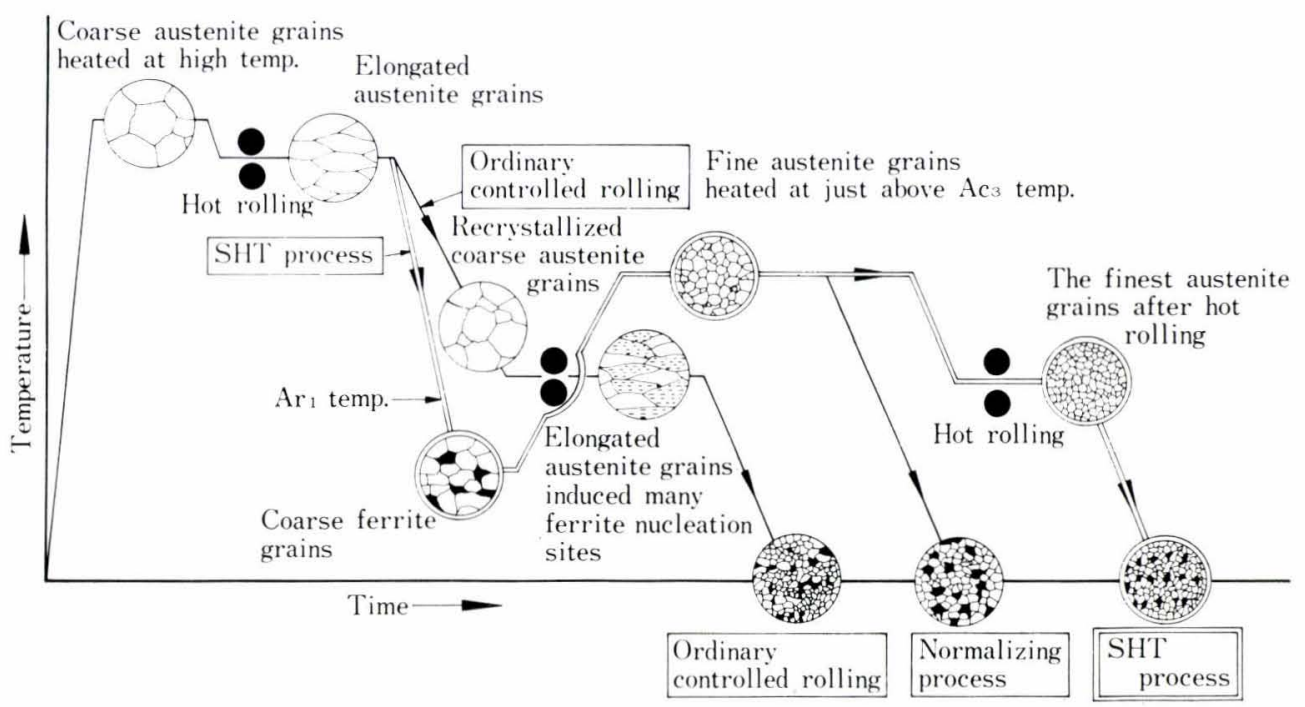

Fig. 3. Schematic diagram of microstructure changes by SHT, ordinary controlled rolling and normalizing method.

1) Controlled rolled steel Heating: $1200^{\circ} \mathrm{C}$ Finishing: $700^{\circ} \mathrm{C}$

2) SHT steel Heating: $930^{\circ} \mathrm{C}$ Reduction: $60 \%$ Finishing: $700^{\circ} \mathrm{C}$

3) Normalized steel Heating: $930^{\circ} \mathrm{C} \times 1 \mathrm{hr}$ Cooling: air cooling

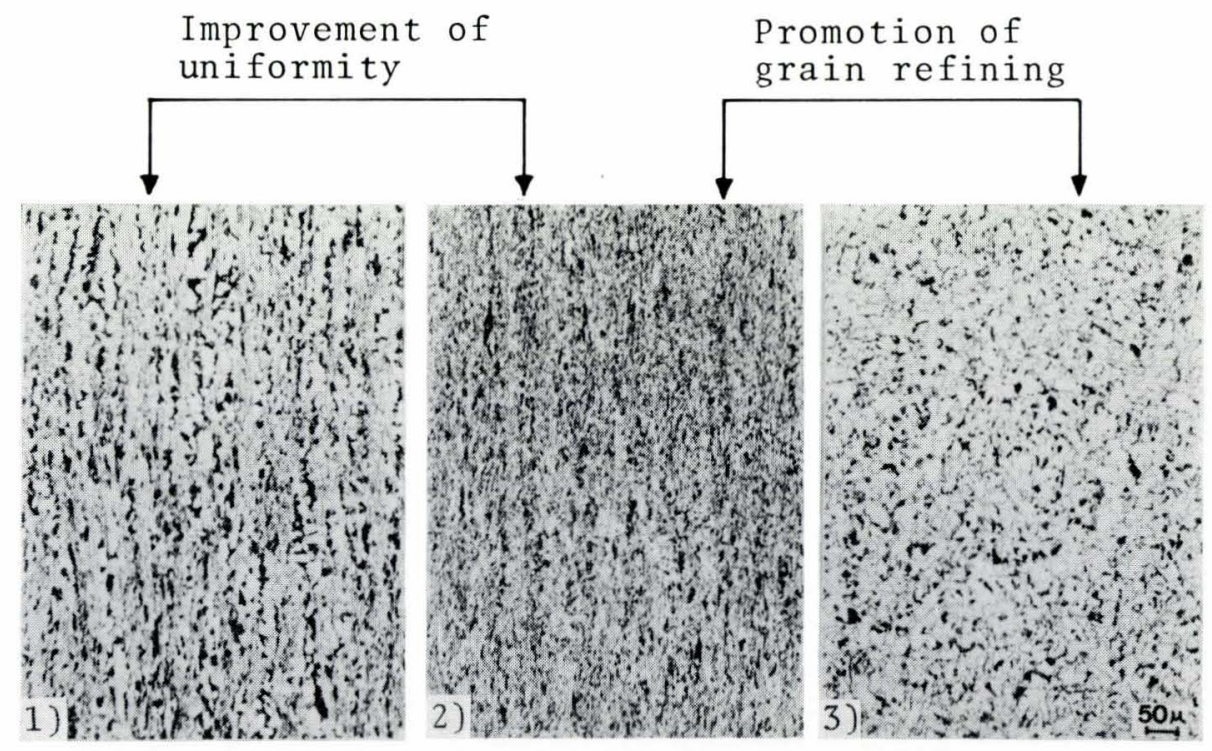

Photo. 1. Microstructures (Steels of the same chemical composition and same plate thickness). 
additionally. This enables us to perform 2-heating and 2-rolling by on-line system. However, in the case of operating only by the SHT process the rolling efficiency is dropped to about $1 / 2$ of that of the ordinary rolling process, which results in the decrease of productivity. Hence, the combined rolling system 3 ) was devised. In this system the SHT rolling and other ordinary rolling are performed parallelly on the 1st and 2nd rolling mills so as to eliminate idle time of the rolling mills. This not only enabled us to prevent lowering of the productivity of the whole rolling line, but to improve the productivity of the whole rolling line as compared to the controlled rolling process.

\section{Development of Computer Control}

So as to perform effectively the complicated SHT and combined rolling a computer control system shown in Fig. 4 has been developed. The reheating furnace control system (Fig. 5) is a unique, unparalleled computer control system which enables us to discharge material at the intended temperature regardless of material charging temperatures and material sizes and allows us to minimize unit fuel consumption without overheating materials in the furnace. It is the first heating furnace control system placed in commercial operation in Japan. ${ }^{12-15)}$ Its highly accurate

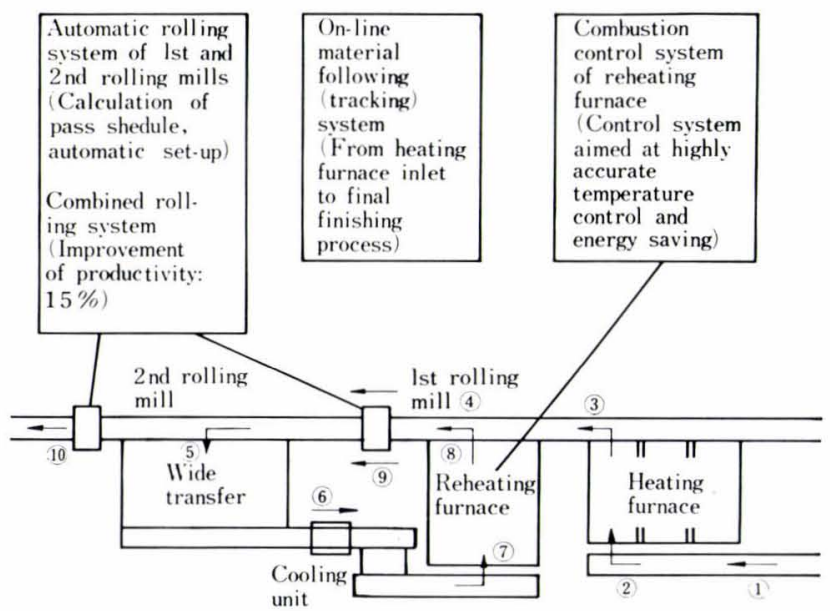

Fig. 4. Layout and computer control system of SHT line. control of furnace temperature contributes to ensuring stable high quality of the SHT steel plates. This reheating furnace control system is applied for other heating furnaces, giving favorable effects in energy saving. It is expected that this system will find wider applications.

\section{Performance of SHT Steel Plates}

Compared to the conventional heat-treated steel plates and controlled rolled steel plates the SHT steel plates have the following advantages:

1) Excellent low temperature toughness,

2) Better uniformity of properties,

3) Better weldability,

4) Excellent economy and mass-productivity, etc.

We have succeeded in the development of a high tensile steel plate for low temperature service which has the abovementioned advantages. Figure 6 shows, for example, the strength-toughness ranges obtained by the conventional methods and by the SHT process. As evident from the diagram, the SHT process ensures more excellent low temperature toughness up to a high strength level as compared to the conventional normalizing process, controlled rolling process, etc. Below are described typical applications of the SHT steel plates and the types of produced steels.

\section{Examples of Application to Cold District Line Pipes}

Table 1 shows the test results of trial application to $\mathrm{X}-70$ grade high toughness line pipes. ${ }^{16)}$ Both the ordinary controlled rolling steel and the SHT steel exhibit sufficient properties suited for X-70 grade gas transportation steel pipes to be used at $-25^{\circ} \mathrm{C}$. However, as for brittle fracture propagation arrest properties determined by Battelle DWTT (Drop Weight Tear Test) the SHT steel affords more stable values than the controlled rolling steel by far. Table 2 shows the results of the production test of heavy-wall high toughness X-65 grade line pipes (having wall thickness of more than $25 \mathrm{~mm}$ ). The SHT process enables us to produce $\mathrm{X}-65$ grade steel pipes having wall thickness of $31.8 \mathrm{~mm}$ and sufficient toughness at $-45^{\circ} \mathrm{C}$. Figure 7 shows DWTT fracture appearance

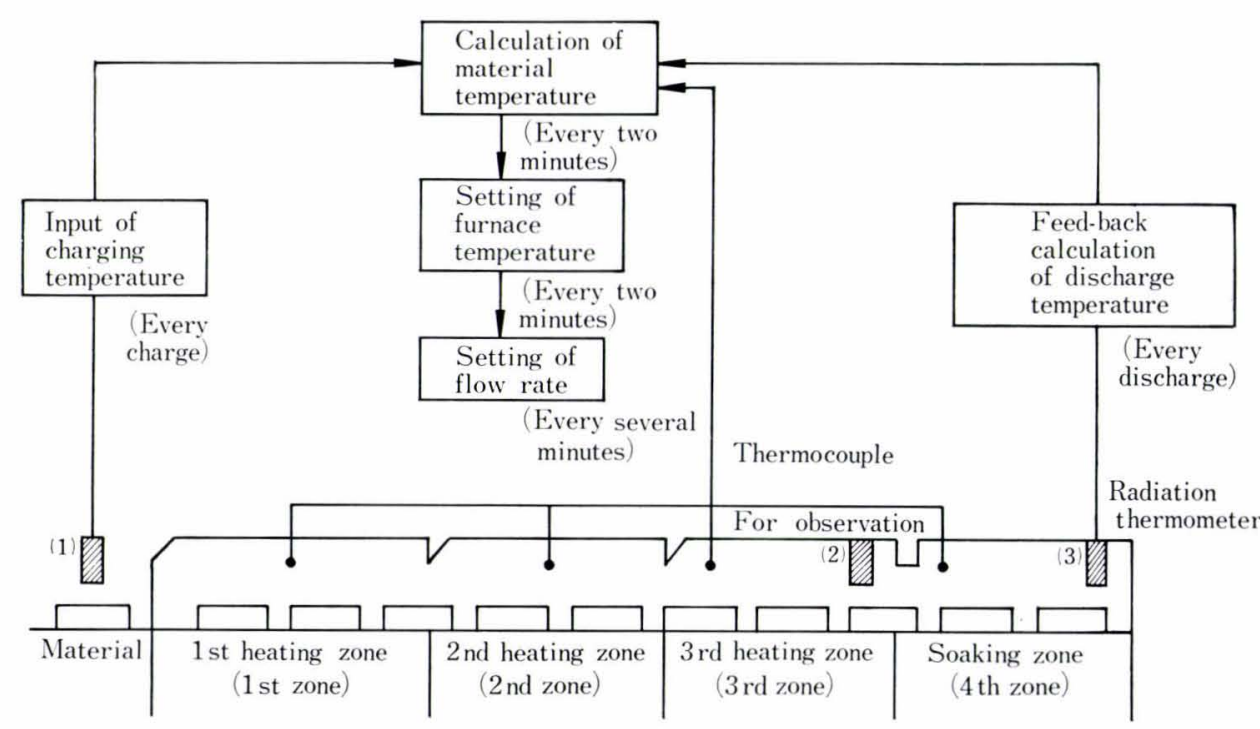

Fig. 5 .

Reheating furnace control system. 
Fig. 6. Low temperature toughness of SHT steel plates.

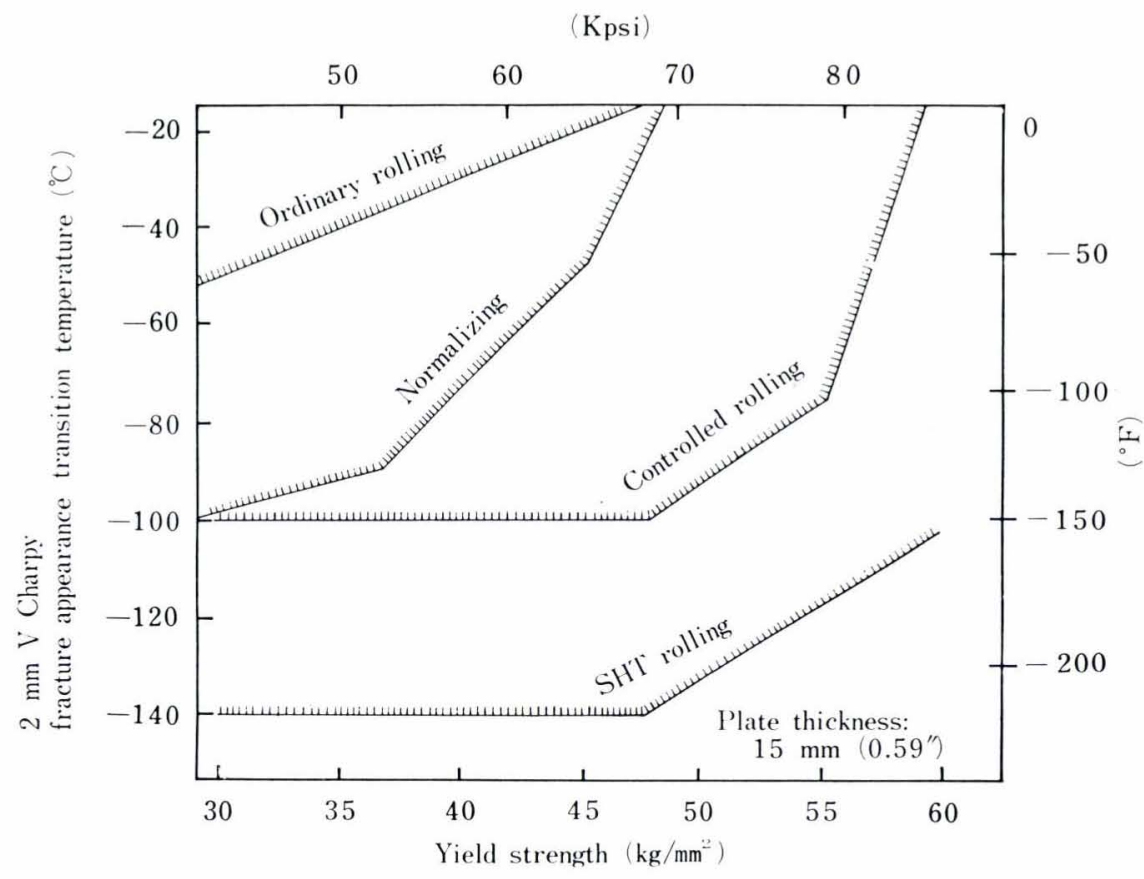

Table 1. Chemical composition and mechanical properties of X-70 grade high toughness line pipes.

\begin{tabular}{|c|c|c|c|c|c|c|c|c|c|c|c|c|c|}
\hline \multirow[b]{2}{*}{ Mark } & \multicolumn{2}{|c|}{$\begin{array}{l}\text { Production } \\
\text { process* }\end{array}$} & \multicolumn{2}{|c|}{ Size } & \multicolumn{9}{|c|}{ Chemical composition (wt $\%$ ) } \\
\hline & Plate & Pipe & $\begin{array}{l}\text { Outer } \\
\text { dia. } \\
(\mathrm{mm})\end{array}$ & $\begin{array}{c}\text { Wall } \\
\text { thickness } \\
(\mathrm{mm})\end{array}$ & C & $\mathrm{Si}$ & Mn & $\mathrm{P}$ & $\mathrm{S}$ & $\mathrm{Nb}$ & $\mathrm{V}$ & $\mathrm{Al}$ & Others \\
\hline $1 \mathrm{~A}$ & SHT & UO & 1220 & 18.3 & 0.09 & 0.28 & 1.26 & 0.019 & 0.005 & 0.027 & 0.08 & 0.045 & $\begin{array}{l}\text { Addition of } \mathrm{Cu}, \mathrm{Cr} \text {, } \\
\text { Mo (Less than } 0.20 \text { ) }\end{array}$ \\
\hline $1 \mathrm{~B}$ & SHT & UO & 1220 & 18.3 & 0.06 & 0.26 & 1.46 & 0.016 & 0.004 & 0.030 & 0.08 & 0.038 & ” \\
\hline $1 \mathrm{G}$ & SHT & GFE & 1220 & 18.3 & 0.07 & 0.35 & 1.51 & 0.011 & 0.004 & 0.041 & 0.09 & 0.046 & $\begin{array}{l}\text { Addition of } \mathrm{Cu}, \mathrm{Cr} \\
\text { (Less than 0.20) }\end{array}$ \\
\hline $1 \mathrm{~A}^{\prime}$ & GR & UO & 1220 & 18.3 & 0.09 & 0.28 & 1.26 & 0.019 & 0.005 & 0.027 & 0.08 & 0.045 & $\begin{array}{l}\text { Addition of } \mathrm{Cu}, \mathrm{Cr} \text {, } \\
\text { Mo (Less than } 0.20 \text { ) }\end{array}$ \\
\hline $1 \mathrm{G}^{\prime}$ & GR & GFE & 1220 & 18.3 & 0.07 & 0.35 & 1.51 & 0.011 & 0.004 & 0.041 & 0.09 & 0.046 & $\begin{array}{l}\text { Addition of } \mathrm{Cu}, \mathrm{Cr} \\
\text { (Less than } 0.20 \text { ) }\end{array}$ \\
\hline
\end{tabular}

\begin{tabular}{|c|c|c|c|c|c|c|c|c|}
\hline \multirow{4}{*}{ Mark } & \multicolumn{4}{|c|}{ Tensile properties (C direction) } & \multicolumn{4}{|c|}{ Notch toughness (C direction) } \\
\hline & \multirow{3}{*}{$\begin{array}{c}\text { Yield } \\
\text { strength } \\
\left(\mathrm{N} / \mathrm{mm}^{2}\right)\end{array}$} & \multirow{3}{*}{$\begin{array}{c}\text { Tensile } \\
\text { strength } \\
\left(\mathrm{N} / \mathrm{mm}^{2}\right)\end{array}$} & \multirow{3}{*}{$\begin{array}{l}\text { Yield } \\
\text { ratio } \\
(\%)\end{array}$} & \multirow{3}{*}{$\begin{array}{c}\text { Elongation } \\
(\%)\end{array}$} & \multicolumn{3}{|c|}{ V Charpy } & \multirow{3}{*}{$\begin{array}{l}\text { B-DWTT } \\
\begin{array}{c}\text { 85\% FATT } \\
\left({ }^{\circ} \mathrm{C}\right)\end{array}\end{array}$} \\
\hline & & & & & \multirow{2}{*}{$\begin{array}{c}50 \% \text { FATT } \\
\left({ }^{\circ} \mathrm{C}\right)\end{array}$} & \multicolumn{2}{|c|}{ Absorbed energy $(\mathrm{J})$} & \\
\hline & & & & & & $-25^{\circ} \mathrm{C}$ & $-45^{\circ} \mathrm{C}$ & \\
\hline $1 \mathrm{~A}$ & 535.6 & 652.8 & 81.4 & 30.0 & -86 & 95 & 84 & -57 \\
\hline 1B & 513.7 & 605.8 & 84.8 & 34.0 & -90 & 227 & 187 & -52 \\
\hline $1 \mathrm{G}$ & 493.1 & 611.7 & 80.5 & 35.1 & -141 & 152 & 122 & -68 \\
\hline $1 \mathrm{~A}^{\prime}$ & 581.3 & 693.0 & 83.9 & 29.6 & -68 & 54 & 52 & -31 \\
\hline $1 \mathrm{C}^{\prime}$ & 541.0 & 637.1 & 85.0 & 34.3 & -82 & 222 & 156 & -31 \\
\hline
\end{tabular}

* CR : Controlled rolling, UO : U- and O-forming process, CFE : Cage forming process.

transition temperature curves of $\mathrm{X}-70$ grade and heavy-wall X-65 grade steel pipes. Partial special piping for transit station of natural gas transportation pipeline requires a high toughness at $-60^{\circ} \mathrm{C}$. To satisfy this requirement by ordinary heat treatment, it is necessary to add 2 to $3 \%$ of $\mathrm{Ni}$. However, the SHT process only requires a $\mathrm{Ni}$ addition of about 0.5 to $1 \%$. Moreover, when the required properties are the same as those of the materials obtained by the conventional processes, the SHT process ensures the saving of resources (saving of alloying elements).

\section{Applications as E Grade Steel for Shipbuilding and as Low Temperature Service Steel}

As for the E grade steel plates to be used for the purpose of arresting brittle fracture ${ }^{17)}$ or low tempera- 
Table 2. Chemical composition and mechanical properties of X-65 grade heavy-wall high toughness line pipes.

\begin{tabular}{|c|c|c|c|c|c|c|c|c|c|c|c|c|c|}
\hline \multirow{2}{*}{ Mark } & \multicolumn{2}{|c|}{$\begin{array}{l}\text { Production } \\
\text { process }\end{array}$} & \multicolumn{2}{|c|}{ Size } & \multicolumn{9}{|c|}{ Chemical composition (wt \%) } \\
\hline & Plate & Pipe & $\begin{array}{l}\text { Outer } \\
\text { dia. } \\
(\mathrm{mm})\end{array}$ & $\begin{array}{c}\text { Wall } \\
\text { thickness } \\
(\mathrm{mm})\end{array}$ & C & $\mathrm{Si}$ & $\mathrm{Mn}$ & $\mathrm{P}$ & $\mathrm{S}$ & $\mathrm{V}$ & $\mathrm{Nb}$ & $\mathrm{Al}$ & Others \\
\hline $2 \mathrm{~A}$ & SHT & UO & 1220 & 26.3 & 0.06 & 0.26 & 1.46 & 0.016 & 0.004 & 0.08 & 0.030 & 0.038 & $\begin{array}{l}\text { Addition of } \mathrm{Cu}, \mathrm{Cr} \text {, } \\
\text { Mo (Less than } 0.20)\end{array}$ \\
\hline $2 \mathrm{~B}$ & SHT & $\mathrm{RB}^{*}$ & 1220 & 31.8 & 0.09 & 0.27 & 1.34 & 0.009 & 0.005 & 0.10 & 0.028 & 0.063 & $\begin{array}{l}\text { Addition of } \mathrm{Cu}, \mathrm{Ni} \\
\text { (Less than } 0.30)\end{array}$ \\
\hline $2 \mathrm{G}^{\prime}$ & CR & UO & 914 & 26.2 & 0.07 & 0.30 & 1.41 & 0.014 & 0.005 & 0.06 & 0.030 & 0.035 & $\begin{array}{l}\text { Addition of } \mathrm{Ni} \mathrm{Mo} \\
\text { (Less than } 0.20 \text { ) }\end{array}$ \\
\hline
\end{tabular}

\begin{tabular}{|c|c|c|c|c|c|c|c|c|}
\hline \multirow{4}{*}{ Mark } & \multicolumn{4}{|c|}{ Tensile properties (C direction) } & \multicolumn{4}{|c|}{ Notch toughness (C direction) } \\
\hline & \multirow{3}{*}{$\begin{array}{c}\text { Yield } \\
\text { strength } \\
\left(\mathrm{N} / \mathrm{mm}^{2}\right)\end{array}$} & \multirow{3}{*}{$\begin{array}{l}\text { Tensile } \\
\text { strength } \\
\left(\mathrm{N} / \mathrm{mm}^{2}\right)\end{array}$} & \multirow{3}{*}{$\begin{array}{c}\text { Yield ratio } \\
(\%)\end{array}$} & \multirow{3}{*}{$\begin{array}{c}\text { Elongation } \\
(\%)\end{array}$} & \multicolumn{3}{|c|}{ V Charpy } & \multirow{3}{*}{$\begin{array}{c}\text { B-DWTT } \\
\begin{array}{c}85 \% \text { FATT } \\
\left({ }^{\circ} \mathrm{C}\right)\end{array}\end{array}$} \\
\hline & & & & & \multirow{2}{*}{$\begin{array}{c}50 \% \text { FATT } \\
\left({ }^{\circ} \mathrm{C}\right)\end{array}$} & \multicolumn{2}{|c|}{ Absorbed energy $(\mathrm{J})$} & \\
\hline & & & & & & $-25^{\circ} \mathrm{C}$ & $-45^{\circ} \mathrm{C}$ & \\
\hline $2 \mathrm{~A}$ & 455.8 & 575.4 & 79.3 & 44.1 & -93 & 244 & 205 & -53 \\
\hline $2 \mathrm{~B}$ & 454.7 & 547.8 & 83.0 & 58.0 & -101 & 192 & 168 & -65 \\
\hline $2 \mathrm{G}^{\prime}$ & 469.6 & 570.6 & 82.3 & 43.9 & -62 & 182 & 116 & -20 \\
\hline
\end{tabular}

* Roll bending.

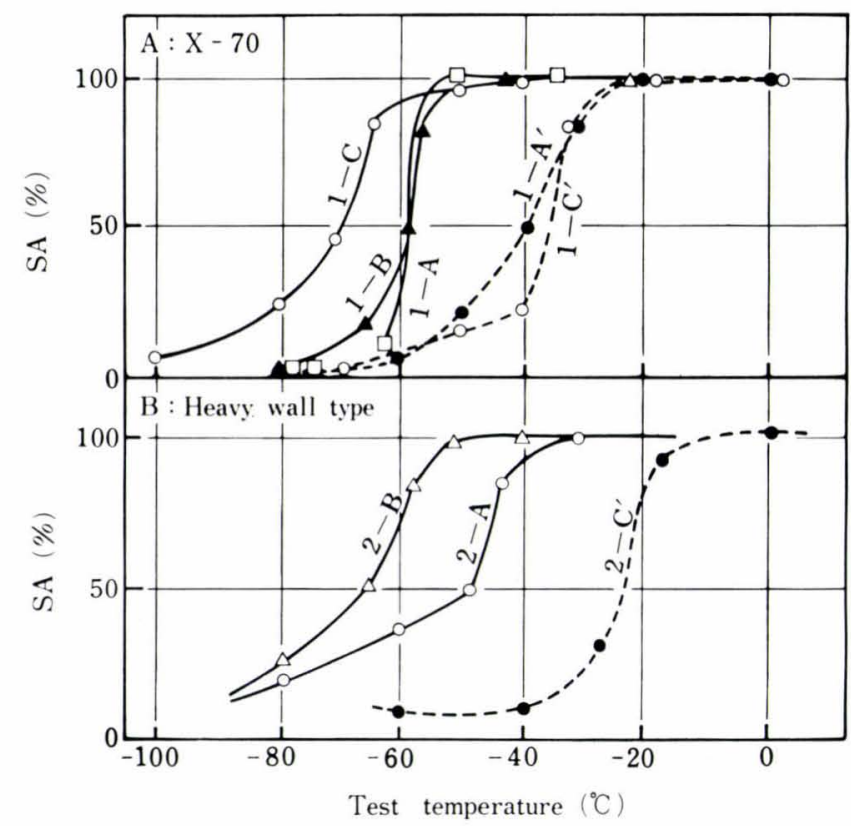

Fig. 7. B-DWTT transition curves of tested steel pipes (Marks refer to Tables 1 and 2).

ture service steel plates for LPG ships, etc., the normalizing process or other equivalent heat treatments are required by various standards. However, the SHT steel plates have been approved as E grade steel and low temperature service steel as shown in Table 3. Hence, it may be regarded that the properties obtained by the thermo-mechanical treatment of the SHT process are acknowledged as equal to those obtained by the conventional heat treatment. Some examples of the properties of the SHT steel plates for low temperature service are shown in Table 4 and Fig. 8.
Table 3. Approval of SHT plates.

\begin{tabular}{|c|c|c|}
\hline Classifications & Name of society & Grade of specification \\
\hline $\begin{array}{l}\text { WES low } \\
\text { temperature } \\
\text { service steel }\end{array}$ & $\begin{array}{l}\text { The Japan } \\
\text { Welding } \\
\text { Engineering } \\
\text { Society }\end{array}$ & $\begin{array}{l}\text { LT29-IV-80G-60A } \\
\text { LT33-IV-90G-60A } \\
\text { LT37-IV-120G-90A }\end{array}$ \\
\hline \multirow[t]{3}{*}{$\begin{array}{l}\text { Low } \\
\text { temperature } \\
\text { service steel } \\
\text { for } \\
\text { shipbuilding }\end{array}$} & $\begin{array}{l}\text { Nippon Kaiji } \\
\text { Kyokai }\end{array}$ & $\begin{array}{l}\text { KL24A, KL24B } \\
\text { KL33 } \\
\text { KL37 }\end{array}$ \\
\hline & $\begin{array}{l}\text { Det Norske } \\
\text { Veritas }\end{array}$ & $\begin{array}{l}\text { NV2-3, NV4-3 } \\
\text { NV2-4, NV4-4 }\end{array}$ \\
\hline & $\begin{array}{l}\text { Lloyd's Register } \\
\text { of Shipping }\end{array}$ & $\begin{array}{l}\text { LT0, LT20 } \\
\text { LT40, LT60 }\end{array}$ \\
\hline \multirow[t]{5}{*}{$\begin{array}{l}\text { E grade } \\
\text { steel for } \\
\text { shipbuilding }\end{array}$} & $\begin{array}{l}\text { Nippon Kaiji } \\
\text { Kyokai }\end{array}$ & $\begin{array}{l}\text { KE, KE32 } \\
\text { KE36, KE46 }\end{array}$ \\
\hline & $\begin{array}{l}\text { American Bureau } \\
\text { of Shipping }\end{array}$ & $\begin{array}{l}\text { E, EH32 } \\
\text { EH36 }\end{array}$ \\
\hline & $\begin{array}{l}\text { Det Norske } \\
\text { Veritas }\end{array}$ & $\begin{array}{l}\text { NVE, NVE27 } \\
\text { NVE32, NVE36 }\end{array}$ \\
\hline & $\begin{array}{l}\text { Lloyd's Register } \\
\text { of Shipping }\end{array}$ & $\begin{array}{l}\text { E, EH27S } \\
\text { EH32, EH34S } \\
\text { EH36 }\end{array}$ \\
\hline & $\begin{array}{l}\text { Korean Register } \\
\text { of Shipping }\end{array}$ & $\begin{array}{l}\text { RE, RE32 } \\
\text { RE36, RE46 }\end{array}$ \\
\hline
\end{tabular}

\section{Improvement of Weldability}

The SHT process enables us to obtain high strength with less content of alloying elements as compared to the normalizing process, which allows us to improve weldability and makes possible the omitting of the preheating process to prevent weld cracking. Figure 
Table 4. Chemical composition and mechanical properties of SHT steel plate for low temperature service.

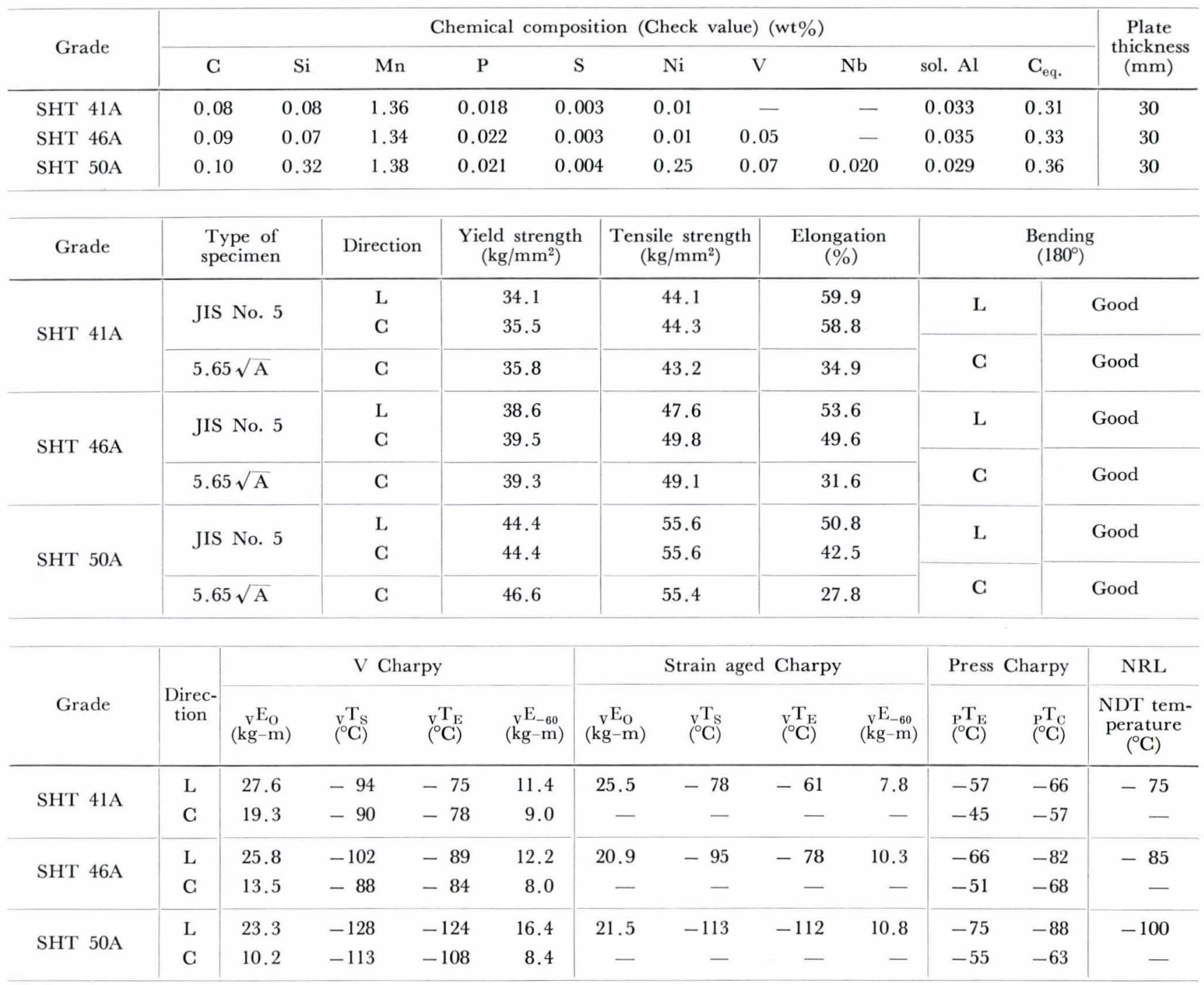

Temperature $\left({ }^{\circ} \mathrm{C}\right)$

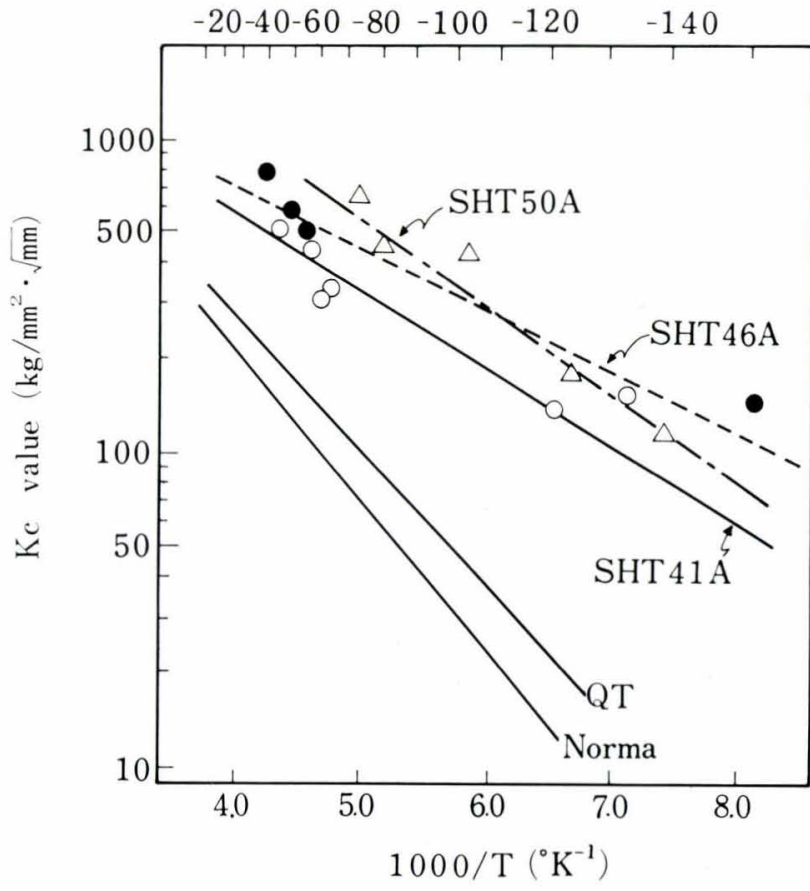

Fig. 8. Results of double tensile test of SHT steel plates.
9 shows $\mathrm{P}_{\mathrm{CM}}$ converted values of chemical composition necessary for SHT steels and normalized steels of EH36 grade (E grade steel with guaranteed yield strength of $36 \mathrm{~kg} / \mathrm{mm}^{2}$ ) of each plate thickness. The $\mathrm{P}_{\mathrm{CM}}$ value is called weld crack susceptibility composition. The lower the $\mathrm{P}_{\mathrm{CM}}$ value, the lower the crack susceptibility of steel and the less crack is formed in the welding process. As seen from Fig. 9, for example, at a plate thickness of $50 \mathrm{~mm}$ the normalized steel requires preheating $\left(120^{\circ} \mathrm{C}\right)$ to prevent cracking of overhead fillet weld, whereas the SHT steel needs no preheat as $\mathrm{P}_{\mathrm{CM}}$ value is low. The typical properties of the EH36 plates produced by the SHT process are given in Table 5 .

\section{Effect of Energy Saving}

The SHT process enables us to save energy by $33 \%$ and $120 \%$ on the average as compared to the normalizing process and quenching and tempering process, respectively. Thus, the energy saving effect of the SHT process is remarkable.

\section{Results of Application}

The SHT steel plates have been used for largediameter steel pipes for cold district gas transporta- 


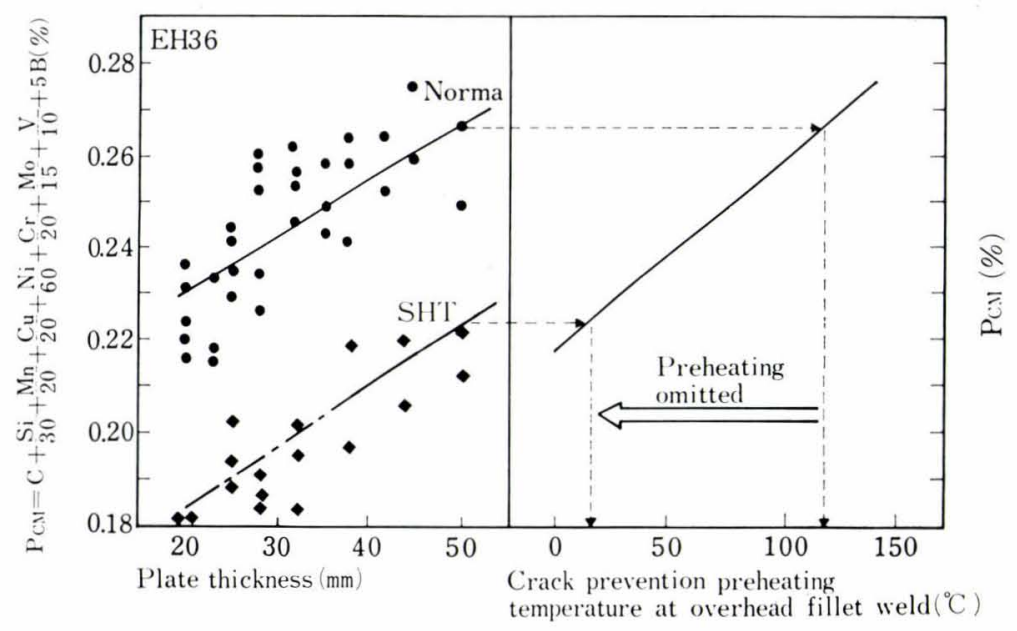

\begin{tabular}{|l|l|}
\hline Effects of omission of preheating & \\
1) Omission of preheating personnel & Reduction of \\
2) Saving of preheating cost & processes \\
3) Increase of welding efficiency & \\
4) Improvement of welding environment & \\
\hline
\end{tabular}

Fig. 9. Preheating conditions for EH36, $50 \mathrm{~mm}$ thick plates.

Table 5. Properties of EH36 steel.

\begin{tabular}{|c|c|c|c|c|c|c|c|c|c|}
\hline \multirow{2}{*}{$\begin{array}{l}\text { Plate } \\
\text { thickness } \\
(\mathrm{mm})\end{array}$} & \multicolumn{9}{|c|}{ Chemical composition (Check value) (wt \%) } \\
\hline & C & $\mathrm{Si}$ & $\mathrm{Mn}$ & $\mathrm{P}$ & $\mathrm{S}$ & $\mathrm{Nb}$ & sol. Al & $\mathrm{C}_{\mathrm{eq}}$ & $P_{\mathrm{CM}}$ \\
\hline 25 & 0.13 & 0.23 & 1.38 & 0.021 & 0.004 & 0.020 & 0.033 & 0.360 & 0.207 \\
\hline 38 & 0.12 & 0.26 & 1.35 & 0.020 & 0.005 & 0.024 & 0.048 & 0.345 & 0.197 \\
\hline 50 & 0.13 & 0.26 & 1.41 & 0.020 & 0.004 & 0.026 & 0.043 & 0.365 & 0.210 \\
\hline
\end{tabular}

\begin{tabular}{|c|c|c|c|c|c|c|c|c|}
\hline \multirow{2}{*}{$\begin{array}{l}\text { Plate } \\
\text { thickness } \\
(\mathrm{mm})\end{array}$} & \multirow{2}{*}{ Direction } & \multicolumn{3}{|c|}{ Tensile test } & \multirow{2}{*}{$\begin{array}{l}\text { Bending test } \\
\text { Radius } 1.5 \mathrm{t} \\
\left(180^{\circ}\right)\end{array}$} & \multicolumn{3}{|c|}{ V Charpy impact test } \\
\hline & & $\begin{array}{l}\text { Yield strength } \\
\qquad\left(\mathrm{kg} / \mathrm{mm}^{2}\right)\end{array}$ & $\begin{array}{l}\text { Tensile strength } \\
\left(\mathrm{kg} / \mathrm{mm}^{2}\right)\end{array}$ & $\begin{array}{c}\text { Elongation } \\
(\%)\end{array}$ & & $\underset{(\mathrm{kg}-\mathrm{m})}{\mathrm{E}_{-40}}$ & $\begin{array}{c}{ }_{(\mathrm{E}} \mathrm{E}_{-10} \\
(\mathrm{~kg}-\mathrm{m})\end{array}$ & $\begin{array}{l}{ }_{\mathrm{V}} \mathrm{T}_{\mathrm{S}} \\
\left({ }^{\circ} \mathrm{C}\right)\end{array}$ \\
\hline \multirow{2}{*}{25} & L & 40.5 & 52.7 & 29.6 & Good & 19.7 & 22.8 & -89 \\
\hline & $\mathrm{G}$ & 40.9 & 52.9 & 30.1 & Good & 11.1 & 11.7 & -83 \\
\hline \multirow{2}{*}{38} & $\mathrm{~L}$ & 39.1 & 52.4 & 36.1 & Good & 20.2 & 23.0 & -92 \\
\hline & $\mathrm{C}$ & 39.5 & 52.4 & 31.9 & Good & 9.8 & 11.5 & -88 \\
\hline \multirow{2}{*}{50} & $\mathrm{~L}$ & 40.2 & 52.2 & 32.8 & Good & 21.8 & 22.9 & -88 \\
\hline & C & 39.3 & 51.9 & 36.0 & Good & 13.5 & 16.4 & -72 \\
\hline
\end{tabular}

tion, large-diameter steel pipes for NGL transportation, jacket steel pipes for platforms, node steel pipes, pressure vessels for ammonia plants, refrigeration tanks of refrigerator ships, large size valves for cold district gas transportation pipelines, large sized industrial machines for cold districts, container carriers, oil tankers, cargo ships, steel constructions, etc. About 80000 tons of the SHT steel plates have been produced so far.

\section{Conclusion}

We have developed a new method of producing high toughness steel plates called SHT process which can be used in the place of conventional methods of production of low temperature service steels. Development of SHT production system including installation of specialized equipments, application of special computer control system, etc. has also played a significant role in the realization of increased pro- ductivity and energy saving, hence making possible the economical supplying of a large amount of steel plates having an excellent low temperature toughness in a short period of delivery.

Thus, the SHT steel exhibits its own outstanding properties as steel plates for gas transportation steel pipes to be used in cold districts and for various other low temperature services. Effectively utilizing the advantages of the SHT process, we intend to supply steel plates of higher quality in the future too.

\section{REFERENCES}

1) S. Hasebe: Tekkokai, 22 (1972), 37.

2) T. Ikeshima: Tetsu-to-Hagané, 65 (1979), 300.

3) E. Miyoshi, M. Fukuda, Y. Hagiwara and Y. Asai: Pattent Bulletin 1974-7293.

4) M. Fukuda, T. Hashimoto and K. Kunishige: Tetsu-toHagané, 58 (1972), 1832.

5) M. Fukuda, T. Hashimoto, K. Kunishige and T. Sawa- 
mura: Tetsu-to-Hagané, 64 (1978), A219.

6) N. Nozaki and M. Fukuda: Pressure Engineering, 16 (1978), 8.

7) T. Hashimoto and M. Fukuda: Tetsu-to-Hagané, 61 (1975), S670 and 671.

8) T. Hashimoto, T. Sawamura and H. Otani: Tetsu-toHagané, 65 (1979), 1425.

9) T. Hashimoto, T. Sawamura and H. Otani: Tetsu-toHagané, 65 (1979), 1589.

10) R. A. Grange: Trans. ASM, 59 (1966), 26.

11) M. Fukuda, T. Hashimoto, T. Suzuki, M. Watanabe and Y. Kato: Sumitomo Metals, 30 (1978), 78.

12) T. Yokoi, H. Kawano, K. Shirai, Y. Nakatsuka and M.
Tatsuwaki: Tetsu-to-Hagané, 63 (1977), S689.

13) Y. Sakamoto, Y. Tamura and M. Tatsuwaki: Tetsu-toHagané, 64 (1978), S734.

14) Sumitomo Metal Industries: Report of 67th Instrumentation Comm., Joint Research Soc., ISIJ, (1977).

15) Sumitomo Metal Industries: Report of 70th Instrumentation Comm., Joint Research Soc., ISIJ, (1978).

16) T. Tanaka, N. Nozaki, K. Bessyo, M. Fukuda and T. Hashimoto: The Sumitomo Search, (1978), No. 19, 47.

17) K. Bessyo, M. Fujimoto and N. Nakano: Preprint of the 23rd National Meeting of Japan Welding Society, Fukui, (1978), 282. 